\section{Digesting the food problem}

David Spurgeon writes from Ottawa on the impact of a symposium held in August to consider how Canada could best contribute in the future to the alleviation of world food shortages

A symposium on the theme "Canada and World Food" has had the paradoxical effect of bringing to the fore some deep-seated concerns about the state of Canadian agriculture itself. Sponsored by the Royal' Society of Canada and the Agricultral Institute of Canada, and featuring some leading figures of Canadian and US agriculture and foreign aid programmes, the meeting also brought into question some of the country's official food aid policies.

Some consensus was reached at the meeting. There seemed to be general agreement that the world food supply was precarious, but that world agriculture was capable of producing enough food to meet demand in the near term. There also appeared to be general agreement with the idea that the world's food security was a political and not an economic or scientific question. Too little emphasis was seen to be placed on agriculture by developing countries.

But the symposium also brought out wide differences of opinion on the effects of food aid and its consequent value to developing nations. On the Canadian position, for example, Gordon A. MacEachern, president of the Agricultural Economics Research Council of Canada, had alarming things to say. He maintained there had been "a serious deterioration in Canada's agriculture-food industry output, trade, productivity performance, and a serious decline in our relative contribution to world food, compared to earlier periods and the performance of other net food exporters, most notably the United States".

Though others pointed out that Canada currently is the world's second largest supplier of food aid, MacEachern said there seemed

little benefit in addressing the relatively attractive world food demand prospects, or the economic potential for Canada expanding its agriculture-food capacity to play a greater role in world food supplies, when its cost-price structure says it can't compete. Pervasive voices from almost all segments of Canada's agriculture and food industries are echoing these sentiments, as are senior agricultural officials in Canada, suggesting that what is 0 presently at stake is the very survival of our agriculture-food industries.

MacEachern acknowledged that
Canada continues to enjoy a favourable trade balance in food, as it always has. But over the past 20 years the country's food and feed exports have not kept pace with the growth of either the Canadian or the world economy or the growth in world food and feed trade. In the past five years, Canada has maintained a net export position for only a few commodities such as grain and oilseeds, and in these output and export performance have remained more or less static.

One reason for this, said MacEachern, is the steady growth in Canada's food imports, two-thirds of which are similar to or the same as foods that can be grown in Canada. Other reasons included the artificial support of the Canadian dollar by the federal government, the high level of wage rates in the industry in Canada, and an effective level of protection of $20-40 \%$ for manufacturing industry, which further raised agricultural costs.

Len Shebeski, dean of the University of Manitoba's faculty of agriculture, quoted a pessimistic comment made in June by Dr Fred Bentley of the University of Alberta's soil science department, who is chairman of the board of trustees of the International Centre for Research in the Semi-arid Tropics (ICRISAT) in India. Without a massive and well-coordinated effort to meet the needs of agriculture, he had said, Canada could become a food deficit nation before the end of this century. Shebeski disputed this. $\mathrm{He}$ believed that Canada's agricultural potential was even greater than the 65 and even $100 \%$ increase over present production others had suggested. He based his prediction on the possibility of doubling the land area devoted to agriculture and a $60 \%$ increase in yield per acre through improved management. Agricultural lands in Canada had the potentialwith present technology-for "more than three times present production of field crops and more than ten times the present ruminant livestock production". And these estimates could be revised upwards "if adequate moisture supplies in the more arid regions of western Canada could be assured."

Shebeski wondered, however, whether Canada ought to reach such production figures. "Because Canada, territorially, is the second largest country in the world, there has developed a popular belief-often voiced-that it is the bread basket of the world," he said.

\author{
Sorry, for copyright \\ reasons some images \\ on this page may not \\ be available online
}


Those of us involved in agriculture know that this is a myth. An examination of a world map depicting the agriculture lands of the world shows that Canada's component of the world's present 3.6 billion acres of crop land is approximately 5\% . Canada's strategic position in the current world food situation does not arise from a high tonnage of food outputs, but rather from the large proportion of her total production available for off-shore consumption.

This production, he intimated, should not be relied upon freely by developing countries to fill their food shortages. The costs of claiming the 20 million hectares of potentially arable land of low fertility would be enormous. Crops produced would be modest in quantity and marginal or submarginal in profitability. The food produced would be thousands of miles from where it would be needed.

As an alternative, Shebeski proposed that the Canadian government, through the International Development Research Centre (IDRC) or the Canadian International Development Agency, make available to developing countries the money it would cost to bring large areas of potential Canadian land into food production. This money could then be used to bring into production land areas with the agricultural potential of the Indus-GangesBrahmaputra plain of North India, or parts of Brazil, where experiments have shown production possibilities of more than 70 bushels per acre. He had struck on a note that was echoed in much of the conference: investments in food production to meet shortages in developing countries should be made in those countries rather than in developed ones.

David Hopper, president of the IDRC, said food assistance should not be denied in cases of genuine emergency or hardship. But imports had in some cases in the past held domestic farm prices below levels that would have prevailed in the recipient countries had the imports not been available, and this had destroyed the incentives to generate local increases in food production. Where the food aid was essentially free, its sale within the country by the recipient government had directly augmented national treasury resources, reducing the need to tax more heavily or to encourage larger savings for domestic investment programmes. That blunted incentives for local development, and removed any urgency to look further into measures to promote the more rapid development of indigenous farming.

Fred Bentley proposed that, as a minimum, every food-deficient lessdeveloped country should be required to increase the budget for agriculture by an amount at least equal to the value of food aid received, without any diminution in the percentage of the national budget already being allocated to the agnicultural sector. Allternatively, recipients could add the funds to their population control programmes. But T. K. Warley, of the School of Agricultural Economics and Extension Education at the University of Guelph, Ontario, defended food aid, saying it had served many purposes beyond providing increased food supplies to hungry people in poor countries, including the general transter of resources to developing countries, support of the balance of payments and thus maintenance of high rates of economic growth, and promotion of political stability and allegiances. Food aid, he said, should be used to accelerate agricultural and rural development, alleviate hunger in specific target groups, and help build minimum stocks of basic foodstuffs.

Frank Shefrin, director of the Canada Department of Agriculture's international liaison service, summed up the magnitude of the world problem. He said that it was not enough to increase the production of food. There had to be increases in food production in the poorer countries and by the small farmers, so that imports of food would not exceed their means of paying. The food had to be produced where it was needed and get to those who need it. Just to stay at the present per capita food production, developing countries could require an annual investment in agriculture of about $\$ 20$ billion, of which $60-70 \%$ would have to come from the countries themselves unless there was a substantial increase in capital assistance.

Findings of the latest report of the International Food Policy Research Institute (IFPRI) in Washington were $U$ also revealed. Projecting food shortfalls of some 82 developing countries (containing roughly half the earth's population) by comparing prospective food production if performance continues in the next 15 years as it has in the past 15, IFPRI has come up with the following forecasts:

- A total food grain deficit among those countries with less than $\$ 300$ GNP per capita in 1973 of $70-85$ million tons by 1990 (12 million tons in 1975).

- A need for some 35 million metric tons over and above the projected production in 1990 just to provide for population increases in these countries (maintaining per capita consumption at 1975 levels).

Potential shortfalls by 1990 among all developing countries included in the study of 120-145 million tons, a figure which approaches the total volume of world grain trade in recent years.

- A potential shortfall of 21-25 million tons by 1990 in India, which has almost half the people in low-income

\section{Sorry, for copyright reasons some images on this page may not be available online}

Onloading in Canada

\section{Sorry, for copyright reasons some images on this page may not be available online}

\section{Offloading in India}

food deficit countries. To meet this, an increase in production of $3 \frac{1}{2} \%$ a year would be required, compared to the historical $2 \frac{1}{2} \%$.

- Deficits of 6-8 million tons each for Bangladesh and Indonesia. For Bangladesh, production would need to increase almost $4 \frac{1}{2} \%$ a year compared to a historical rate of $1 \frac{1}{2} \%$. For Indonesia, the rate should be $4 \frac{1}{3} \%$ instead of the historical $3 \%$.

- A deficit of 18-21 million tons facing Nigeria, which would require $5-5 \frac{1}{2} \%$ increase a year (historic rate $\frac{1}{2} \%$ ).

- An increase to $3 \frac{1}{2}-4 \%$ required in Sahel countries to avoid a shortage of $3 \frac{1}{2}$ million tons (historic rate $-\frac{1}{2} \%$ ).

- To meet nutritional needs, most lowincome food-deficit countries need an additional $\frac{1}{2}-1 \%$ growth rate over and above those necessary to meet market demand. 